\title{
Removal of calcium and magnesium ions from hard water using modified Amorphophallus campanulatus skin as a low cost adsorbent
}

\author{
Ajeng Yulianti Dwi Lestari*, Abdul Malik, Sukirman, Muhammad Irfan Ilmi, and Mahathir Sidiq \\ Chemical Engineering Department, Faculty of Industrial Technology, Universitas Islam Indonesia, Jalan Kaliurang KM 14,5 Besi \\ Sleman 55584, Yogyakarta, Indonesia
}

\begin{abstract}
Low cost adsorbent from Amorphophallus campanulatus skin has successfully synthesized to remove calcium and magnesium ions in the syntetic hard water. A. campanulatus skin were dried, crushed into powder form and modified by acid modification. A batch experiment with various parameters was used in this research. Various isotherm models were applied to fit the experimental data. Adsorption capacity of $\mathrm{Ca}$ and $\mathrm{Mg}$ on $\mathrm{KB}$ and $\mathrm{KM}$ adsorbents in $100 \mathrm{ppm}$ solution respectively 10,85 mg/g, 27,64 mg/g, 1,79 mg/g and $20,1 \mathrm{mg} / \mathrm{g}$. It was found out that the adsorption behavior of hard mineral ions by adsorbents match well with the Dubinin Radushkevich isotherm model. Based on the result, it can be concluded that a acid modified A. campanulatus skin is quite potential as a new low cost adsorbent which is expected to be applied to Indonesian groundwater which have high degree of hardness.
\end{abstract}

\section{Introduction}

Hard water is water that has high mineral content mainly calcium and magnesium ions. Water hardness causes a variety of problems in either house hold water supply or industrial water systems, such as the buildup of lime-scale that fouls plumbing and promotes galvanic corrosion, and the formation of membrane scaling in seawater desalination. Water softening is a process to remove the water hardness from various water streams and the conventional methods include the lime-soda ash treatment and ion exchange resin [1]. Permanent hardness is usually caused by the presence of calcium and magnesium sulfates in water which become more soluble as temperature rises. Therefore, permanent hardness cannot be removed by boiling. It can be removed by using a water softener which works on the principle of ion exchange in which calcium and magnesium ions are exchanged with sodium or potassium ions, reducing the concentration of hardness minerals to tolerable levels and thus making the water softer and giving it a smoother feeling [2].

Adsorption is the process that can separate objects which neither impossible to be applied nor impracticed by conventional techniques [3]. Zeolite, activated carbon, activated alumina are used as adsorbent. But recently there are researches that concern on making of the novel adsorbent. This novel adsorbent is made not only from unusual sources but also made from the polisaccarides. Polisaccarides which is choosen as adsorbents due to their easily to synthesize, have large adsorption capacity and cheap [4]. Elephant foot yam contains polisaccarides that not explore before. So this project focused on evaluation of the characteristics of the acid modification of the elephant foot yam skin adsorbents and their ability to adsorp both ion $\mathrm{Ca}^{2+}$ and $\mathrm{Mg}^{2+}$ in aqueous solution.

\section{Material and methods}

The main materials of this subject are A. campanulatus skin, pure distilled water, Merck's hydrochloric acid and Merck's sodium hydroxide. The selected fresh foot yam tubers is obtain from the farmers at Ngawi, East Java, Indonesia which has the itchy yellowish tuber.

\subsection{Pretreatment of $A$. campanulatus skin}

A. campanulatus fresh tuber firstly cleaned then peeled the skin. The skin then dried in the oven at $50^{\circ} \mathrm{C}$ for 24 hours. The dried skin then grinded and sieved on 200 mesh sieve after that the sieved skin has been stored into a sterile plastic bag

\subsection{Modification of A. campanulatus skin}

Sieved A. campanulatus skin then modified with acid to improve its adsorption ability. Five hundred grams of sieved A. campanulatus skin then dissolved into 2 litres of $\mathrm{HCl}$ solution for 3 hours. This acid mixture the neutralized with $\mathrm{NaOH}$ solution until $\mathrm{pH} 7$ was reached. The neutral mixture then separated with filter paper. The distilate was dried in oven at $60^{\circ} \mathrm{C}$ for $1-2$ days. The modified skin then stored into a sterile plastic bag.

\footnotetext{
${ }^{*}$ Corresponding author: aydlestari@uii.ac.id
} 


\subsection{Characterization of the adsorbents}

There are two characterization of this project. They are suface morphology characterization and chemical bonding characterization. The adsorbents surface morphology was visualized by FEI Inspect S50 Scanning Electron Microscope (SEM). The chemical bonding was determined with Thermo Nicolet Avatar 360 Fourier Transform Infrared Spectroscopy (FTIR).

\subsection{Determination adsorption properties of adsorbent}

Isotherm adsorption was determined by mixing $1.5 \mathrm{~g}$ of sample adsorbents (KB and $\mathrm{KM}$ ) with $25 \mathrm{~mL}$ differential concentration of $\mathrm{Ca}$ and $\mathrm{Mg}$ artificial hard water (100, 200, 300, 400, 500 [ppm]). Mixture then mixed well for about 30 minutes. After the mixing the adsorbent separated from the filtrate by the Whatmann 40 ashless filter paper, the final concentration of the mixture then analized using Perkin Elmer PinAAcle 900T Atomic Absoprtion Spectrofotometer (AAS). Experimental data then fitted with Langmuir, Freundlich, Temkin and Dubinin Radushkevich isotherm model and studied which the appropriate model(s).

\section{Result and discussion}

\subsection{Effect of acid modification}

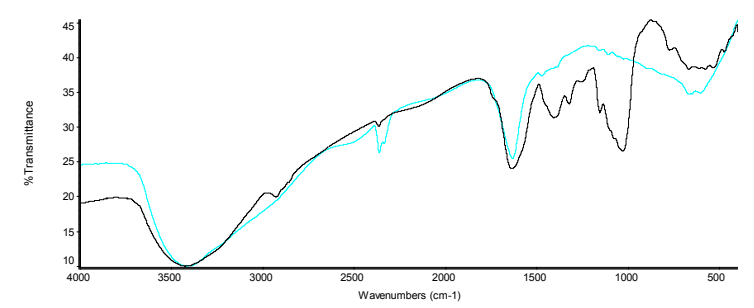

Figure 0.1 FTIR Spectrums of KB and KM

Figure 3.1 represented FTIR spectra of the chemical bonding that occurred in the adsorbent KB and KM. The black line represented $\mathrm{KB}$ spectrum and the light blue line represented KM spectrum. Spectra of KB and KM showed the $-\mathrm{OH}$ bonds on wavelength around $3.400 / \mathrm{cm}$, the $\mathrm{C}=\mathrm{O}$ bonds on wavelength around $1.800 / \mathrm{cm}$, the $\mathrm{C}-\mathrm{O}$ bonds on wavelength $1.000 / \mathrm{cm}$. After the modification, both $\mathrm{KB}$ and KM's $-\mathrm{OH}$ bonds was tend to be more symmetrical. It can be said that the process of modification with hydrochloric acid may alter-OH bond.

\subsection{Characterization of the adsorbents}

SEM photograph showed in Figure 3.2 below with 5.000x magnification of $\mathrm{KB}$ and $500 \mathrm{x}$ magnification of $\mathrm{KM}$. Figure KB that represent the pure dried A. campanulatus skin and figure KM represent the modified dried $A$. campanulatus skin. It showed that KM has larger pore than KB due to the diference of magnification. SEM showed that the pore diameter of KB is $412,6 \mathrm{~nm}$ and the pore diameter of $\mathrm{KM}$ is $64,69 \mu \mathrm{m}$. Modification process influences the morpfology and chemical bonding of adsorbents. Based on those characteristic, the KM sample assessed to have a better adsorption ability.
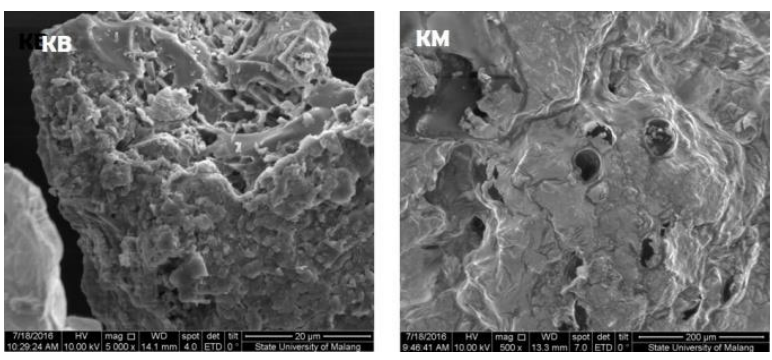

Figure 0.2 SEM Graphs of KB and KM

\subsection{Effect of initial concentration}

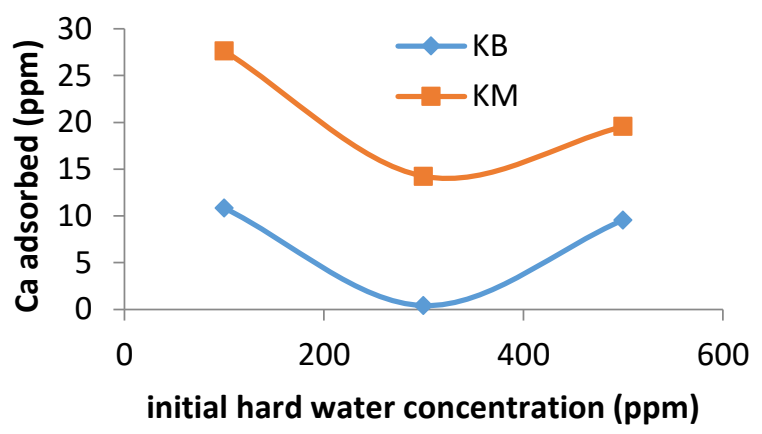

Figure 0.3 Calcium adsorption capacity on $\mathrm{KB}$ and $\mathrm{KM}$ in various concentration

The relationship between the initial $\mathrm{Ca}$ and $\mathrm{Mg}$ concentration and the adsorption capacities on $\mathrm{KB}$ and $\mathrm{KM}$ was studied. As shown in Figure 3.3 above, the adsorption capacities of $\mathrm{KB}$ and also $\mathrm{KM}$ for $\mathrm{Ca}$ was correlated with the initial $\mathrm{Ca}$ ion concentration because the process was depend on the concentration. When the concentration rose from $100 \mathrm{ppm}$ to $500 \mathrm{ppm}$, the adsorption capacities of KB and KM increased from 10.85 to $27.64 \mathrm{mg} / \mathrm{g}$ in $100 \mathrm{pmm}$ solution, 0.42 to $14.24 \mathrm{mg} / \mathrm{g}$ in $300 \mathrm{ppm}$ solution and 9.57 to $19.56 \mathrm{mg} / \mathrm{g}$ in $500 \mathrm{ppm}$ solution. Figure 3.4 below represents the correlation between $\mathrm{Mg}$ initial concentration and $\mathrm{Mg}$ adsorbed both on $\mathrm{KB}$ and $\mathrm{KM}$ surface. When the concentration rose from $100 \mathrm{ppm}$ to $500 \mathrm{ppm}$, the adsorption capacities of $\mathrm{KB}$ and $\mathrm{KM}$ increased from 1.79 to $20.1 \mathrm{mg} / \mathrm{g}$ in $100 \mathrm{pmm}$ solution, 11.33 to $33.66 \mathrm{mg} / \mathrm{g}$ in $300 \mathrm{ppm}$ solution and 10.92 to $21.84 \mathrm{mg} / \mathrm{g}$ in $500 \mathrm{ppm}$ solution. 


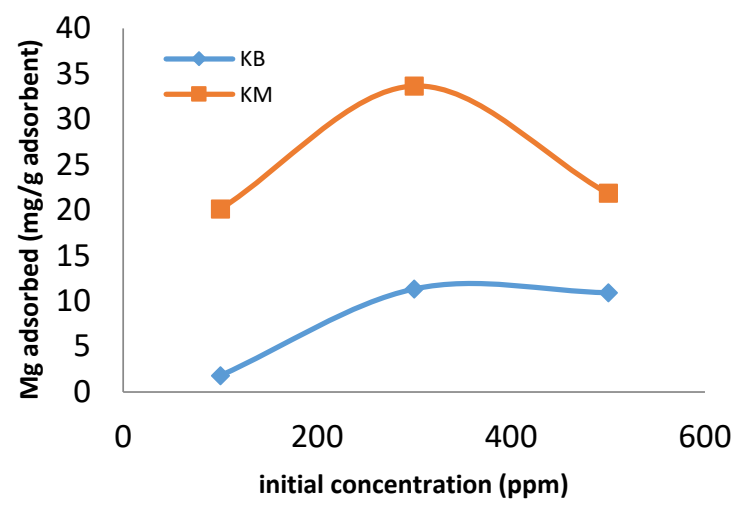

Figure 0.4 Magnesium adsorption capacity on KB and $\mathrm{KM}$ in various concentration

\subsection{Adsorption isoterm of calcium and magnesium ion into the adsorbents}

The adsorption isotherms showed the relations between the concentration of adsorbat and its degree of accumulation of $\mathrm{Ca}$ and $\mathrm{Mg}$ onto surface of adsorbent at room temperature. Several models of adsorption isotherm have been used to fit to the experimental data. Fitting model used to evaluate isotherm performances for water adsorption. These isotherm models are the Freundlich model, Langmuir model, Temkin model and Dubnin Radushkevich model. Figure 3.5 and Figure 3.6 showed the plot of data isoterm of $\mathrm{Ca}$ adsorption onto the $\mathrm{KB}$ and $\mathrm{KM}$ adsorbents. They showed that the $\mathrm{Ca}$ adsorption onto $\mathrm{KB}$ and $\mathrm{KM}$ are suitable with Dubinin isotherm. Figure 3.7 and Figure 3.8 showed the plot of data isoterm of $\mathrm{Mg}$ adsorption onto the KB and KM adsorbents. They showed that the $\mathrm{Mg}$ adsorption onto $\mathrm{KB}$ and $\mathrm{KM}$ are also suitable with Dubinin isotherm.

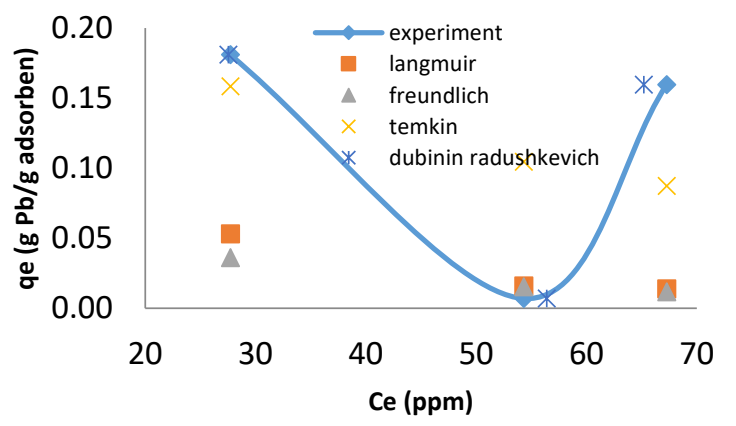

Figure 0.5 Ca onto KB

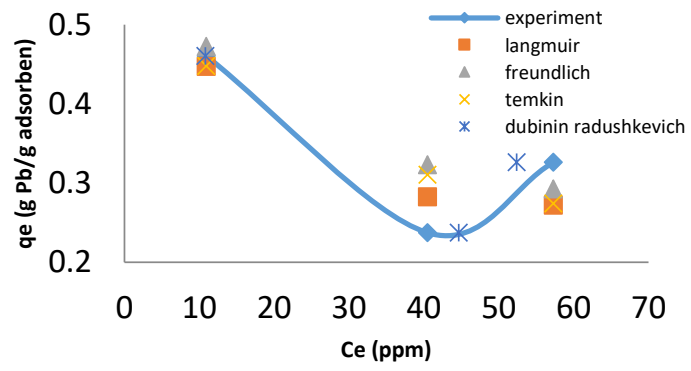

Figure 0.6 Ca onto KM

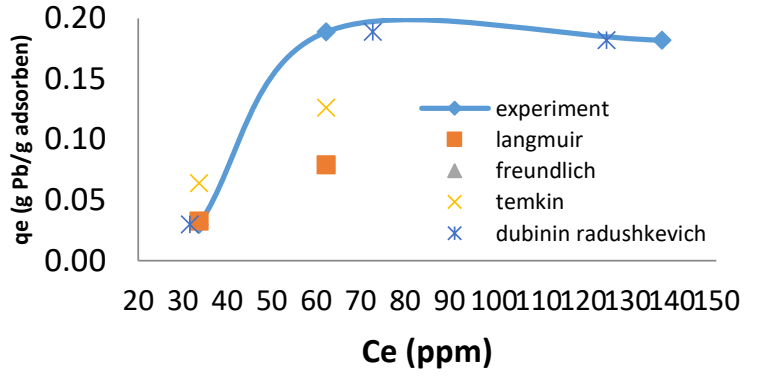

Figure 0.7 Mg Sorption on KB

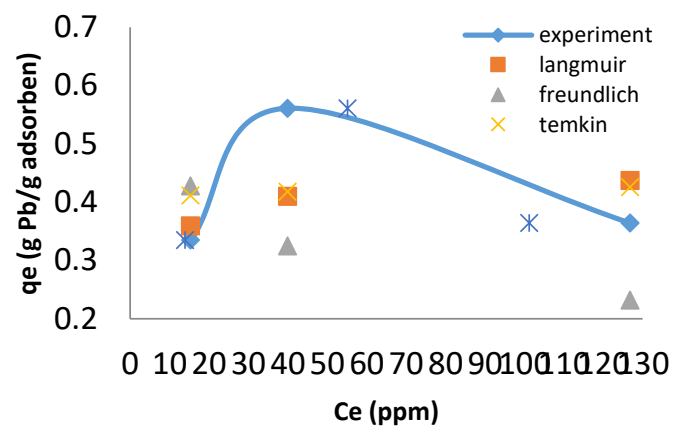

Figure $0.8 \mathrm{Mg}$ Sorption on $\mathrm{KM}$

Table 3.1 showed the details of $\mathrm{Ca}$ adsorption isotherm parameters onto $\mathrm{KB}$ and $\mathrm{KM}$ adsorbents.

Table 0.1 Calcium Isothem Parameters onto KB and KM

\begin{tabular}{lcccccc}
\hline & \multicolumn{3}{c}{ Langmuir } & \multicolumn{3}{c}{ Freundlich } \\
\cline { 2 - 7 } & $\mathrm{K}_{\mathrm{L}}$ & $\mathrm{q}_{0}$ & $\mathrm{R}^{2}$ & $\mathrm{~K}_{\mathrm{F}}$ & $\mathrm{n}$ & $\mathrm{R}^{2}$ \\
\hline KB & 0,044 & 0,009 & 0,131 & 2,418 & 0,789 & 0,101 \\
KM & 0,207 & 0,249 & 0,601 & 0,946 & 3,448 & 0,968 \\
\hline & \multicolumn{3}{c}{ Temkin } & \multicolumn{3}{c}{ Dubinin Radushkevich } \\
\cline { 2 - 7 } & $\mathrm{A}_{\mathrm{t}}$ & $\mathrm{B}$ & $\mathrm{R}^{2}$ & $\mathrm{~K}_{\mathrm{ad}}$ & $\mathrm{q}_{\mathrm{s}}$ & $\mathrm{R}^{2}$ \\
\hline KB & 0,005 & 0,080 & 0,153 & 1,674 & 120,542 & 0,994 \\
$\mathrm{KM}$ & 0,001 & 0,105 & 0,676 & 0,902 & 77,246 & 0,988 \\
\hline
\end{tabular}

Table 3.2 showed the details of $\mathrm{Mg}$ adsorption isotherm parameters onto $\mathrm{KB}$ and $\mathrm{KM}$ adsorbents.

Table 0.2 Magnesium Isotherm Parameters on KB and KM

\begin{tabular}{lcccccc}
\hline & \multicolumn{3}{c}{ Langmuir } & \multicolumn{3}{c}{ Freundlich } \\
\cline { 2 - 7 } & $\mathrm{K}_{\mathrm{L}}$ & $\mathrm{q}_{0}$ & $\mathrm{R}^{2}$ & $\mathrm{~K}_{\mathrm{F}}$ & $\mathrm{n}$ & $\mathrm{R}^{2}$ \\
\hline KB & 0,006 & 0,117 & 0,843 & 0,040 & 0,820 & 0,667 \\
$\mathrm{KM}$ & 0,254 & 0,451 & 0,161 & 0,946 & 3,448 & 0,586 \\
\hline & \multicolumn{3}{c}{ Temkin } & \multicolumn{2}{c}{ Dubinin Radushkevich } \\
\cline { 2 - 7 } & $\mathrm{A}_{\mathrm{t}}$ & $\mathrm{B}$ & $\mathrm{R}^{2}$ & $\mathrm{~K}_{\mathrm{ad}}$ & $\mathrm{q}_{\mathrm{s}}$ & $\mathrm{R}^{2}$ \\
\hline KB & 0,055 & 0,102 & 0,647 & 2,512 & 196,960 & 0,962 \\
$\mathrm{KM}$ & 0,005 & 0,007 & 0,003 & 1,448 & 134,424 & 0,926 \\
\hline
\end{tabular}

\subsection{Comparison of $\mathrm{KB}$ and $\mathrm{KM}$ with other $\mathrm{Ca}$ adsorbent}

Table 3 showed the list of adsorption capacity of $\mathrm{Ca}$ and Mg by some synthetic adsorbents not only conventional adsorbent but also low cost natural based adsorbent. This study said that the KM has the adsorption ability better than $\mathrm{KB}$ for bith ions. Another advantage of KM especially compared to adsorbent conventional is the availability of raw materials for the manufacture of 
adsorbent abundant sources of biomass, easily regenerated, adsorbent regeneration after use more environmental friendly.

Table $0.3 \mathrm{Mg}$ and Ca adsorption capacity on various adsorbents

\begin{tabular}{|c|c|c|c|c|c|}
\hline \multirow[t]{2}{*}{ Adsorbent } & \multicolumn{2}{|c|}{$\begin{array}{l}\text { Adsorption Capacity } \\
(\mathrm{mg} / \mathrm{g})\end{array}$} & \multicolumn{2}{|c|}{$\begin{array}{l}\text { Initial } \\
\text { concentration } \\
(\mathrm{mg} / \mathrm{L})\end{array}$} & \multirow[t]{2}{*}{ Reference } \\
\hline & $\mathrm{Ca}^{2+}$ & $\mathrm{Mg}^{2+}$ & $\mathrm{Ca}^{2+}$ & $\mathrm{Mg}^{2+}$ & \\
\hline KB & 10.85 & 1.79 & 100 & 100 & This study \\
\hline $\mathrm{KM}$ & 27.64 & 20.10 & 100 & 100 & This study \\
\hline MPC & $\begin{array}{l}85 \% \\
\text { removed }\end{array}$ & $\begin{array}{l}85 \% \\
\text { removed }\end{array}$ & 208 & 147 & {$[5]$} \\
\hline Quartz sand & 60.00 & & 450 & & {$[6]$} \\
\hline SDBS-SMB & 29.27 & 29.27 & 120 & 120 & [7] \\
\hline $\begin{array}{l}\text { Kaolin based } \\
\text { geopolimer }\end{array}$ & 76.00 & 40.00 & & & [8] \\
\hline
\end{tabular}

\section{Conclusion}

Novel adsorbent was succesfully synthesized from Amorphophallus campanulatus skin modified by hydrochloric acid. The experiment focused on investigation of the effect of modification and the adsorption ability for $\mathrm{Ca}$ and $\mathrm{Mg}$ ions in aquoeus solution. Modification caused KB more porous and the changed the infrared spectrum of $-\mathrm{OH}$ bonding. The adsorption behaviour is dependent on the initial concentration of $\mathrm{Ca}$ and $\mathrm{Mg}$ ion. Adsorption capacity $\mathrm{Ca}$ and $\mathrm{Mg}$ on $\mathrm{KB}$ and $\mathrm{KM}$ in $100 \mathrm{ppm}$ aqueous are $10.85 \mathrm{mg} / \mathrm{g}, 27.64 \mathrm{mg} / \mathrm{g}, 1.79$ $\mathrm{mg} / \mathrm{g}$ and $20.1 \mathrm{mg} / \mathrm{g}$. The adsorption follows the Dubinin isotherm. The study also evaluates that the KM has better adsorption ability than KB. So hydrochloric acid modification on the Amorphophallus campanulatus skin gave a potential application as another low cost natural based adsorbent.
Authors would say thank to Directorate of Research and Community Service Islamic University of Indonesia for the financial support. We also thank Rudi Syah Putra, head of Integrated Laboratory Islamic University of Indonesia and Abdulloh Fuad, head of Central Laboratory of Mineral \& Advanced Materials, Malang State University for their guidance with the experimental element of this research.

\section{References}

1. C. Liu, L. Shi, R. Wang. Jour of Memb Sci, 486, 169176. (2015)

2. MA Tofighy, T Mohammadi. Desal., 268, 208-213. (2011)

3. KS Knaebel. Adsorption Research Inc's publication: 1-21. (2009)

4. DW O'Connell, C Birkinshaw, TF O'Dwyer. Bior Tech, 99, 6709-6724. (2008)

5. HS Altundogan, A Topdemir, M Cakmak, N Bahar. Jour of the Tai Inst of Chem Eng. 1-7. (2015)

6. Y Chen, R Fan, D An, Y Cheng, H Tan. (2016). Jour of Env Sci, article in press (2016).

7. NNA Kadir, M Shahadat, S Ismaii. App Clay Sci, 137, 168-175. (2017)

8. M Naghsh, K Shams. App Clay Sci, 146, 238-245. (2017) 